\title{
THE COLOUR SIGNALING PROCESS IN TURKISH SIGN LANGUAGE
}

\author{
Erhan Aslan - Gülşen Danacı - Neșe Arslan
}

\begin{abstract}
This study deals with the analysis of the signs used to name colors in Turkish Sign Language (TID). The aim of the study was to reveal how color signaling process works in TID and to describe the major linguistics characteristics in terms of arbitrariness, conventionality, iconicity. For the data of the study a corpus consisting of 16 colors was prepared and three hearing and speech impaired people, regardless of their age, education, socio-economic, and socio-cultural background, were randomly chosen to conduct the study. The subjects were asked through written Turkish to express those colors in TID. The analysis revealed that some color signaling in TID proved to be arbitrary and conventional and most of the signs seem to iconic.
\end{abstract}

Key words: Turkish Sign Language (TID), arbitrary, conventional, iconic, color signaling, semantics

\section{TÜRK İŞARET DİLINDE RENK ADLANDIRMA SÜRECİ}

\section{$\ddot{O}_{z e t}$}

Bu çalışma Türk Işaret Dili’nde (TID) renk adlandırma sürecini incelemektedir. Çalışmanın amacı TID’de renk adlandırma sürecinin nasıl işlediğini ortaya çıkarmak ve TID’in nedensizlik, uzlaşımsallı ve görüntüsel göstergesellik gibi dilsel özelliklerini betimlemektir. Çalışmanın verisini oluşturmak için 16 renkten oluşan bir bütünce hazırlanmış; yaş, eğitim, sosyo-ekonomik ve sosyo-kültürel durumları göz ardı edilerek işitme ve konuşma engelli üç kişi rasgele seçilmiştir. Katılımcılara yazılı Türkçe yoluyla bütüncedeki renkleri TID’ de ifade etmeleri istenmiştir. Çalışmanın sonucunda, TID’in nedensizlik ve uzlaşımsallık özelliklerini gösterdiği ve bazl renklerin görüntü göstergesel olarak ifade edildiği görülmüştür.

Anahtar sözcükler: Türk Işsaret Dili (TID), nedensiz, uzlaşımsal, görüntü göstergesel, renk adlandırma, anlambilim 


\section{INTRODUCTION}

A sign language is a system of communication which is composed of gestures made through the hands and other parts of the body in order to meet the basic functions of every aspect of face to face communication (Crystal, 1992:353). In this respect it might be said that a sign language is a non-verbal and visual communication used widely among hearing and speech impaired people.

The study of sign languages in linguistic perspectives has been of a rather recent interest of inquiry. This is primarily because of the fact that the definition of language has been limited to its being only a specialized sound signaling system which every human is genetically endowed with. Nevertheless, the enhance of the interest in studying sign languages by the 1960s has revealed that languages do not have to be necessarily an oral medium of communication. We are led to this idea by the fact that sign languages bear some sort of systematic and conventional rules similar to those of spoken languages. Therefore, it would not be wrong to state that sign languages are unique systems of communication and their scientific analysis must be included in the scope of linguistics (Crystal, 1987:220).

Since the study of sign languages as an area of scientific inquiry does not go back too far, the structure of individual signs in sign languages and the grammar of sign languages in relation to their four micro-level of linguistic analysis (phonology, morphology, syntax, semantics) have been mainly dealt with so far (Açan, 2001:1). However, a full account of other aspects of linguistic behaviour concerning sign languages is yet to be revealed.

In spite of the recency of sign languages studies within the scope of linguistics, it is possible to give an account of the basic properties of sign languages if we take a look at what has been investigated and drawn out about sign languages so far:

- Sign languages, like verbal languages, do have a grammatical structure. In contrary to what is being assumed, their structures are not any simpler than those of verbal languages.

- Every sign language has unique grammatical rules peculiar to them and the signs used to denote every concept are common to the users. In this respect, the signs used in sign languages are different from the gestures and pantomimes we use in verbal languages.

- Every nation has its own sign language. For instance, the sign language used in America (ASL) does not resemble that of used in Germany. These two sign languages are as different as English and German are.

- Although a sign language is affected by the verbal language spoken around it, it still bears a unique grammar. That is to say, Turkish and Turkish Sign Language (TID) do not have to necessarily resemble one another. 
- As it is the case in spoken languages, a sign language is also to be learned at an early age; otherwise, it becomes difficult for those hearing impaired people to learn a sign language if they have not acquired it till they are five or six. (see, http://turkisaretdili.ku.edu.tr/ )

Turkish sign language (TID, henceforth) is the sign language used by the deaf community in Turkey. Most hearing and speech impaired people in Turkey (approximately, 90\%) acquire TID after the critical age (after the first five years of age). In this respect, it might be said that almost all TID users acquire TID at a later age.

It has been known that there are some differences and standardization problems in the acquisition process of TID. For instance, it is possible to observe some differences of signaling among the students from 7 different schools for hearing and speech impaired people in Istanbul. Even though there are some differences among the signs of TID users, mutual intelligibility among the users is apparent.

In Turkey studies on hearing and speech impaired people are mostly undertaken by such fields as education and medicine. As for linguistic studies, apart from the word-based glossary published by Turkish Republic, Ministry of Education, there are no other written materials, archives, or dictionaries that can fully describe TID

If we consider the attempts which have been made so far in order to give a linguistic analysis of TID, we observe that it has not been dealt with properly. When compared to the linguistic analyses of sign languages in the western world, it is found out that TID remains excluded from the attention of linguists and thus, is still to be described. For this reason, this project aims at contributing to the linguistic description of TID focusing particularly on the color naming process. Thus, it can be said that the study is undertaken to approach TID from a semantic point of view.

\section{LITERATURE REVIEW}

Although TID has still so much to be investigated, there have been some major recent attempts which shed light on the current studies on TID. Among these attempts the following studies might be considered:

The project of H. Haberdar (2005) 'Sakl Markov Model Kullantlarak Görüntüden Gerçek Zamanlı Türk Işaret Dili Tanıma Sistemi' deals with TID with an aim to establish a satisfactory recognition of the signs used in TID.

The study of H. Dikyuva (2006) titled as 'Education, General History and Materials of Turkish Sign Language' gives an exhaustive explanation about the background of TID, ways and methods and materials to be utilized in the teaching of TID. 
Z. Ulrike works with the grammatical structure of TID and the spread of its use within the educational system. Among the best known works of her are 'Sign Language of Turkey: The story of a hidden language (2002), and 'Aspects of Türk Işaret Dili (Turkish Sign Language) (2003).

The studies of A. Özyürek, D. İlkbaşaran focus on the understanding the grammar of TID and its relation to other sign languages of the world. (see, http://turkisaretdili.ku.edu.tr.)

'A Study on Sign Languages and Turkish Sign Language' by Z. A. Açan, one of the major linguistic works, deals with TID in terms of its basic linguistic characteristics.

\section{STATEMENT OF THE PROBLEM}

It is known that there have been some common misconceptions and wrongly held opinions about sign languages. Among these are the following:

- There is only one sign language all around the world.

- Sign languages are not proper ways of communication; they merely consist of gestures and pantomimes.

- They do not have a unique grammar.

- Sign languages are invented by people speaking verbal languages in order to help those speech and hearing impaired people.

The major reason behind these invalid opinions about sign languages is the fact that there is so little linguistic research on sign languages and therefore, sign languages are not properly known and regarded as unique ways of communication.

As this is also the case for TID, the prominence of TID in the public eye has long been underestimated and the level of awareness among people has never been high. In this respect, the existence of the problem becomes more apparent when we see that TID has a lower status and awareness than Turkish, although TID bears quite a lot of differences compared to the verbal Turkish.

\section{PURPOSE}

The main purpose of this study is to describe the colour naming process in TID and to contribute to the studies on TID so as to avoid the misconceptions surrounding the TID. 
As might be derived from the scope of the research, this study is not an attempt to give a full linguistic account of TID. Rather, it aims at figuring out general and descriptive findings about the working of colour naming process in TID.

\section{RESEARCH QUESTIONS}

This study looked for some answers for the following questions:

- How does the colour naming process work in TID?

- Does TID show iconic characteristics in terms of colour naming?

- Is there an arbitrary relationship between the signs and the colors in TID?

- Is the relationship between the signs and the colors conventionally established?

\section{BOUNDARIES OF THE STUDY}

This study is limited to the description of some characteristics of color naming process in TID. The major aim of the study is to contribute to the linguistic description of TID and provide public awareness about the linguistic recognition of TID. The findings presented in this study are to be regarded as preliminary background for future research on color naming process in TID and open to every kind of reasonable suggestions and corrections.

The study includes some restrictions in terms of its scope and findings:

- The study was carried out with three subjects, two of which were male and one of which is female. The subjects were chosen randomly from the members of Hearing and Speech Impaired People Local in Ankara.

- The age, education, socio-economic, socio-cultural backgrounds of the subjects were all disregarded.

- Although the researchers were not adept at using TID, they did not consult any translator during the data collection process to communicate with the subjects. As the subjects were able to read and write Turkish, the communication was mostly established through written Turkish and partly through some non-standard signs used by the researchers. 
- The subjects were presented a corpus which was limited to 16 colors, and the subjects were asked to express these colors in TID. While the subjects were translating the color names into TID, the researchers recorded this process in a video camera.

- The subjects were voluntarily committed to the study; however, the video recording process was actualized in an unnatural communicative environment. That is, the natural communication of the subjects was not recorded.

- The corpus was presented the subjects in written Turkish.

\section{METHODOLOGY}

The study employed a qualitative method of investigation and it was carried out as a field work in terms of its focus on describing the color naming process in TID. The data of the study consist of a corpus which includes 16 color names, all of which were written in Turkish.

The preparation of the corpus and the interpretation of the findings depended upon some certain stages:

- In this study three subjects were used all of whom use TID as the basic medium of communication.

- The corpus was based upon 11 colors which are claimed by Berlin \& Kay (1969, qtd. in Palmer, 1976:71) to exist in all natural languages and other 5 colors that the researchers added to the corpus. These colors were red, yellow, blue, green, white, black, brown, purple, pink, claret red, grey, orange, light blue, light green, navy blue, lilac.

- Before the corpus was prepared and applied, the researchers visited the local and observed the natural communicative environment of the people there and obtained some preliminary information about TID.

- While the subjects were performing the signs of colors in TID, the process was video-recorded. The record was, then, transferred into a compact disk and the process of data analysis took start.

- No translator was used during the data analysis process. The analysis was wholly based on the interpretations of the researchers.

- The subjects were video-recorded one by one at regular short intervals.

- Within the scope of the study, some non-verbal and non-manual uses of expressions were disregarded. 


\section{THE ANALYSIS AND RESULTS}

\subsection{CORPUS}

RED: signaled by lips in two movements of fingers. One is horizontal and the other is vertical.

YELLOW: signaled by the colour of the teeth when not brushed

BLUE: signaled by eyes

GREEN: signaled by eyes

WHITE: signaled by teeth and collar

BLACK: signaled by darkness

BROWN: signaled in two ways: one by a coffee cup in hand, and the other by touching the jaw at the level of the chest

PURPLE: signaled by the color of the nose when one's got cold

PINK: signaled by both cheek and jaw

CLARET RED: signaled by cherry hung on the ear

GREY: non-iconic; signaled by pointing the thumb to the jaw and also by another hand movement close to the jaw

ORANGE: signaled by the fruit orange

LIGHT BLUE: signaled by adding the sign of 'open' to the front of the sign of 'blue'

LIGHT GREEN: signaled by adding the sign of 'open' in front of the sign of 'green'

NAVY BLUE: signaled by the capital letter of the color name (lacivert)

LILAC: the same as purple

\subsection{THE RESULTS}

As a result of the analysis of the video recordings, TID was found out to have all the colors presented in the corpus. The results revealed that TID employ the colors which Berlin\&Kay (1969, qtd. in Palmer, 1976:71) assumed all natural languages to have. In this respect, TID might be said to be a natural language since it includes all the universal colors in the colour system proposed by Berlin\&Kay.

The data analysis also revealed that the signaling of the majority of the colors seemed to be iconic. These colors were red, yellow, blue, green, white, black, brown, pink (cheek), claret red, orange, navy blue. 
Other colors, however, do not seem to be non-iconic: purple, grey, lilac, pink (jaw). It was not found out that the signs of the colors do not have any direct or indirect relation with any referent in the real world. Therefore, the signaling of these colors is arbitrary and conventional.

\section{DISCUSSION AND CONCLUDING REMARKS}

There is no clear association with the two arbitrary colors purple and grey; however, the researchers associated purple with the color of the nose when one's got cold, and grey with the color of beard.

It was observed that some of the colors are signaled in two different ways. These colors were white, pink, brown, and grey. When the subjects were asked why they signaled some colors in two different ways, they reported that these differences are on regional basis. Thus, this led the researchers to reach at the point that there may be varieties in TID, which are Istanbul and Ankara, on the basis of what the subjects said. However, some of these colors have varieties: white, pink and red. Other colors which are also signaled in two ways may not have regional varieties.

$\begin{array}{lll} & \text { Istanbul } & \text { Ankara } \\ \text { White } & \text { collar } & \text { teeth } \\ \text { Pink } & \text { cheek } & \text { jaw } \\ \text { Red } & \text { vertical } & \text { horizontal }\end{array}$

It was also drawn out from the findings that some colors such as black and red are signaled in different ways by the female subject and the male subjects. This difference may be attributed to the gender differences. It was observed that the way the female subject signals the colors was clearer and more refined compared to that of the male subjects.

Another finding was that the colour inventory of the female subject seems to be wider than that of the male subjects. During the data collection process the male subjects either hesitated or even did not signal some colors such as claret red, lilac. However, the female subjects showed a higher level of performance in signaling the colors in a more determined and elaborate way.

The reason why 5 other colors - orange, light blue, light green, navy blue, lilac(other than Berlin\&Kay's colour system) were added to the corpus was to see whether TID is rich in terms of its colour inventory. After the analysis, it was observed that TID is productive in colour naming process. 
The findings of this study may be used to guide future research towards comparing and contrasting the colour systems of other sign languages to TID and establishing new findings with a substantial contribution to the linguistic description of TID.

\section{REFERENCES}

Açan, A. Z. (2001). A Study on Sign Languages and Turkish Sign Language. Hacettepe Üniversitesi: Yayımlanmamış Yüksek Lisans Tezi.

Crystal, D. (1987). The Cambridge Encyclopedia of Language and Language. Cambridge: Cambridge University Press.

Crystal, D. (1992). An Encyclopedic Dictionary of Language and Languages. Oxford: Blackwell Publishers.

Dikyuva, H. (2006). Education, General History and Materials of Turkish Sign Language (TID). Turkish National Federation of the Deaf: Koç University.

Haberdar, H. (2005). Saklı Markov Model Kullanilarak Görüntüden Gerçek Zamanlı Türk İşaret Dili Tanıma Sistemi. Yıldız Teknik Üniversitesi : Yayınlanmış Yüksek Lisans Tezi.

Özyürek, A., İlkbaşaran, D. (2003) TID Website : http://turkisaretdili.ku.edu.tr.

Palmer, F.R. (1976). Semantics. Cambridge : Cambridge University Press.

Zeshan, U. (2002). Sign Language in Turkey: The Story of a Hidden Language. Turkic Languages Vol. 6:2

Zeshan, U. (2003). Aspects of Turk İşaret Dili (Turkish Sign Language). Sign Languages and Linguistics Vol. 6:1 